\title{
Progress in Neurological Surgery
}

Vol. 14

Series Editor

L.D. Lunsford, Pittsburgh, Pa.

KARGER $\begin{aligned} & \text { Basel·Freiburg } \cdot \text { Paris } \cdot \text { London } \cdot \text { New York } \\ & \text { New Delhi } \cdot \text { Bangkok } \cdot \text { Singapore } \cdot \text { Tokyo } \cdot \text { Sydney }\end{aligned}$ 


\section{Gamma Knife Brain Surgery}

Volume Editors $\quad$ L.D. Lunsford, Pittsburgh, Pa.

D. Kondziolka, Pittsburgh, Pa.

J.C. Flickinger, Pittsburgh, Pa.

75 figures and 34 tables, 1998

M R ER Basel-Freiburg · Paris · London · New York ·

New Delhi $\cdot$ Bangkok $\cdot$ Singapore $\cdot$ Tokyo $\cdot$ Sydney 


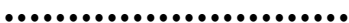

\section{Dade Lunsford, MD, FACS}

University of Pittsburgh

Medical Center

Pittsburgh, Pa., USA

Library of Congress Cataloging-in-Publication Data

Gamma knife brain surgery / volume editors, L.D. Lunsford, D. Kondziolka, J.C. Flickinger.

(Progress in neurological surgery; vol. 14)

Includes bibliographical references and indexes.

1. Brain - Surgery. 2. Radiosurgery. 3. Brain - Diseases. I. Lunsford, L. Dade.

II. Kondziolka, D. (Douglas), 1961- . III. Flickinger, J.C. (John C.) IV. Series.

[DNLM: 1. Radiosurgery. 2. Brain Diseases - surgery. W1 PR673 v. 14 1998WL 368 G193 1998]

RD594.15.G35 $1998 \quad 617.4^{\prime} 81059-$ dc21

ISBN 3-8055-6637-9 (hardcover : alk. paper)

Bibliographic Indices. This publication is listed in bibliographic services, including Current Contents ${ }^{\circledR}$ and Index Medicus.

Drug Dosage. The authors and the publisher have exerted every effort to ensure that drug selection and dosage set forth in this text are in accord with current recommendations and practice at the time of publication. However, in view of ongoing research, changes in government regulations, and the constant flow of information relating to drug therapy and drug reactions, the reader is urged to check the package insert for each drug for any change in indications and dosage and for added warnings and precautions. This is particularly important when the recommended agent is a new and/or infrequently employed drug.

All rights reserved. No part of this publication may be translated into other languages, reproduced or utilized in any form or by any means electronic or mechanical, including photocopying, recording, microcopying, or by any information storage and retrieval system, without permission in writing from the publisher.

C) Copyright 1998 by S. Karger AG, P.O. Box, CH-4009 Basel (Switzerland)

Printed in Switzerland on acid-free paper by Reinhardt Druck, Basel

ISBN 3-8055-6637-9 


\section{Contents}

VII Preface

1 Introduction

Lunsford, L.D.; Kondziolka, D.; Flickinger, J.C. (Pittsburgh, Pa.)

Basic Principles

5 Gamma Knife Technology and Physics: Past, Present, and Future Maitz, A.; Flickinger, J.C.; Lunsford, L.D. (Pittsburgh, Pa.)

21 Radiobiologic Considerations in Gamma Knife Radiosurgery Kondziolka, D.; Lunsford, L.D.; Maitz, A.; Flickinger, J.C. (Pittsburgh, Pa.)

39 Principles of Dose Prescription and Risk Minimization for Radiosurgery

Flickinger, J.C.; Kondziolka, D.; Lunsford, L.D. (Pittsburgh, Pa.)

Vascular Radiosurgery

51 Patient Outcomes after Arteriovenous Malformation Radiosurgery Pollock, B.E. (Rochester, Minn.)

60 Gamma Knife Radiosurgery and Particulate Embolization of Dural Arteriovenous Fistulas, with a Special Emphasis on the Cavernous Sinus

Coffey, R.J. (Rochester, Minn.); Link, M.J. (Jacksonville, Fla.); Nichols, D.A.; Pollock, B.E.; Gorman, D.A. (Rochester, Minn.)

78 Stereotactic Radiosurgery for Cavernous Malformations Kondziolka, D.; Lunsford, L.D.; Flickinger, J.C. (Pittsburgh, Pa.) 
Benign Tumor Radiosurgery

89 Gamma Knife Radiosurgery for Acoustic Neuromas

Lunsford, L.D.; Kondziolka, D. (Pittsburgh, Pa.); Pollock, B.E. (Rochester, Minn.);

Flickinger, J.C. (Pittsburgh, Pa.)

104 Stereotactic Radiosurgery of Meningiomas Kondziolka, D.; Lunsford, L.D.; Flickinger, J.C. (Pittsburgh, Pa.)

114 Gamma Knife Radiosurgery for Pituitary Tumors Witt, T.C. (Indianapolis, Ind.); Kondziolka, D.; Flickinger, J.C.; Lunsford, L.D. (Pittsburgh, Pa.)

128 Stereotactic Radiosurgery for Other Skull Base Lesions Muthukumar, N. (Madurai); Kondziolka, D.; Lunsford, L.D. (Pittsburgh, Pa.)

Frontiers of Radiosurgery

145 Radiosurgery Management of Brain Metastasis from Systemic Cancer Flickinger, J.C.; Kondziolka, D.; Lunsford, L.D. (Pittsburgh, Pa.)

160 Stereotactic Radiosurgery for Glial Neoplasms Kondziolka, D.; Flickinger, J.C.; Lunsford, L.D. (Pittsburgh, Pa.)

175 Stereotactic Radiosurgery in the Treatment of Pineal Region Tumors Subach, B.R.; Lunsford, L.D.; Kondziolka, D. (Pittsburgh, Pa.)

195 Gamma Knife Radiosurgery for the Treatment of Movement Disorders Duma, C.M.; Jacques, D.B.; Kopyov, O.; Mark, R.J.; Copcutt, B.; Gembus, M.; Farokhi, H.K. (Los Angeles, Calif.)

212 Gamma Knife Radiosurgery for Trigeminal Neuralgia Kondziolka, D.; Perez, B.; Flickinger, J.C.; Lunsford, L.D. (Pittsburgh, Pa.)

222 Author Index

223 Subject Index 


\section{. \\ Preface}

The series, Progress in Neurological Surgery, has a long and valuable educational history. The first volume was published by Karger in 1966. The initial distinguished editorial group included Krayenbuhl, Maspes and Sweet. Despite the more recent explosion in neurosurgical publishing over the last 21 years, the value and role of this series will be further shown by the publication of the present volume. When the publishers at Karger came to me with the concept of taking over the editorship, I suggested that the lapse of almost 8 years required rapid introduction of a timely and topical volume. I had been planning for some time to produce a volume summarizing our experience in stereotactic radiosurgery at the University of Pittsburgh Medical Center. A combination of these two goals allowed me to rapidly develop a series of contributing authors who could be 'leveraged' to produce a timely group of papers summarizing our experience.

Other guest-edited volumes of Progress in Neurological Surgery are expected on a biennial basis. I hope that readers will take advantage of the rejuvenation of this important series. I would like to express my deep appreciation to the entire team of colleagues who participated as authors in the book and wish to provide special acknowledgement to Charlene Baker, Mary Ann Vincenzini, Peggy Schmitt, and Stephanie Lunsford for their enormous contribution to the preparation of this book. Without them it could not and would not be done. 